\title{
TINGKAT PROFESIONALITAS GURU DALAM PEMBELAJARAN EKONOMI DI SMAN 1 SOOKO MOJOKERTO
}

\author{
Yosia Dian Purnama Windrayadi ${ }^{1}$ \\ Economic Education Program, Faculty of Economics, State University Malang \\ dianyosia@gmail.com.
}

\begin{abstract}
Abstrak
Facing growing competition in the age of education right now, all parties need to equate the thinking and attitudes to promote improved quality education. then as the author of I want to know how far the level of professionalism of teachers in study refers to Permendiknas the year of 2007 that already assigned. The author would like to know how the professional in learning ranging from planning, implementation, and evaluation. Here the author took rumusah problems about the application of professional teachers in the planning, implementation and evaluation and then coupled with a supporting factor and the factor restricting teachers become professional. From the results that have been obtained through observation and documentation indicate that economics teacher at SMAN 1 Sooko still not be said because of the four professional competence set forth in this Government Department, second economics teacher This is not yet able to meet all of them, like the relationship with a less harmonious society, and also the relationship of fellow teachers who have not undertaken smoothly, then the results of the second study video recording the teacher hadn't meet the hours of lessons on the set, and also still using learning methods according to the learners tend to be boring, thus there are 6 factors that support the success ofachieving professional teacher SMAN 1 Sooko i.e. factor the presence of expertise each teacher, community support, a factor of dukngan colleagues as teachers, government intervention, the demands of the teachers ' code of ethics, and the last factor is the scrutiny of the Department of education. In addition there is a supporting factor there is definitely a factor that inhibits a teacher could become a professional atSMAN 1 Sooko Mojokerto, factors such a barrier is the lack of fulfillment of the hour lesson, there is a lack of social interaction, the relationship is not good against fellow teachers, and also the use of inappropriate methods of learning in students. This indicates that the economics teacher at SMAN 1 Sooko from the four competenciesno one has perfectly fulfilled, since there are many challenges from within and from outside the teacher, but we recommend that teachers must be better learn to understand the conditions environment, and also the feedback from learners over what has been presented so these existing barrier factor can be reduced and economics teacher at SMAN 1 Sooko growing professional, and this is also a reflection for authors in particular for increasingly encouraged as to how these four competencies will be fulfilled properly if the author worked as educators. Stanford University was set upin order for educators that is really able to meet the province's existing competencies, because teachers are professional in produce with the fulfillment of the four competencies that already exist.
\end{abstract}

Keywords: The level of professionalism, economic studies

History of Article:

Received: (15 Januari 2017), Accepted : (15 Februari 2017), Publised : (06 Maret 2017)

\section{Citation:}

Yosia Dian Purnama Windrayadi (2017) Tingkat Profesionalitas Guru Dalam Pembelajaran Ekonomi Di SMAN 1 Sooko Mojokerto . [The Level of Teacher Professionalism in Economic Learning At SMAN 1 Sooko Mojokerto]. Jurnal Pendidikan Ekonomi, 10(1), 40-44

(C) UniversitasNegeri Malang 


\section{PENDAHULUAN}

Menghadapi pesatnya persaingan pendidikan di era global ini, semua pihak perlu menyamakan pemikiran dan sikap untuk mengedepankan peningkatan mutu pendidikan. Pihak-pihak yang ikut meningkatkan mutu pendidikan adalah pemerintah, masyarakat, stake holder. Kalangan pendidik serta semua sub sistem pendidikan yang mempunyai partisipasi meningkatkan kulitas pendidikan di Indonesia.

Dari pihak yang disebutkan di atas, dalam pembahasan tulisan ini yang disoroti hanya masalah "guru", sebab "guru menjadi fokus utama dari kritik-kritik atas ketidakberesan sistem pendidikan". Namun tidak dapat dimungkiri bahwa, "pada sisi lain guru juga menjadi sosok yang paling diharapkan dapat mereformasi tataran pendidikan. Guru menjadi mata rantai terpenting yang menghubungkan antara pengajaran dengan harapan akan masa depan pendidikan di sekolah yang lebih baik.

Barghava et al. (2011:77) menyatakan bahwa faktor terpenting dalam pembelajaran adalah guru. Guru dalam proses pembelajaran di kelas dipandang dapat memainkan peran penting terutama dalam membantu peserta didik untuk membangun sikap positif dalam belajar, membangkitkan rasa ingin tahu, mendorong kemandirian, serta menciptakan kondisi-kondisi untuk sukses dalam belajar. Saragih (2008) menyatakan bahwa kompetensi minimal seorang guru baru adalah menguasai keterampilan mengajar dalam hal membuka dan menutup pelajaran, bertanya, memberi penguatan, dan mengadakan variasi mengajar.

Di negara kita, bukan rahasia lagi bahwa masyarakat mempunyai harapan yang berlebih terhadap guru. Keberhasilan atau kegagalan sekolah sering dialamatkan kepada guru. Justifikasi masyarakat tersebut dapat dimengerti karena guru adalah sumber daya yang aktif, sedangkan sumber daya-sumber daya yang lain adalah pasif (BSNP, 2005). Oleh karena itu, sebaik-baiknya kurikulum, fasilitas, sarana dan prasarana pembelajaran, tetapi jika kualitas gurunya rendah maka sulit untuk mendapatkan hasil pendidikan yang bermutu tinggi.

Penulis meneliti kajian tentang kinerja dan profesionalitas guru masih merupakan hal penting untuk dibahas di dalam tulisan ini, yang hasilnya dapat dijadikan sebagai dasar dalam upaya perancangan dan pengem-bangan kinerja dan kompetensi guru dalam pembelajaran. Banyaknya guru yang kurang profesional juga menyebabkan buruknya kualitas pendidikan. Terlalu sulitnya guru untuk mencapai profesionalisme menjadi alasan mendasar mengapa guru di Indonesia sulit berkembang. Untuk mencapai kualitas pendidikan yang baik, maka perlu merubah sistem pendidikan dan pendidiknya kearah perbaikan. Peran sebuah organisasi profesi juga berperan aktif disini. Karena setiap profesi yang membutuhkan profesionalitas membutuhkan tempat atau wadah yang menaungi mereka guna menjadi landasan dalam berbuat sesuatu.

Penulis ingin mengetahui penerapan 4 kompetensi guru profesional yang sudah ditetapkan di Undang-undang . karena kebanyakan guru pada era sekarang telah lulus program sertifikasi yang didalamnya terdapat 4 kompetensi guru profe-sional yang harus dicapai sebelum mendapat sertifikat guru profesional. Dan dari situlah penulis ingin mendalami lebih lanjut tentang guru ekonomi di SMAN 1 Sooko khususnya dalam menerapkan 4 kompetensi profesional tersebut.

Tujuan yang akan di inginkan oleh penelitian ini adalah (1) Agar memahami penerapan profesionalitas dalam tahap persiapan, pelaksanaan, dan evaluasi pembelajaran pada bidang studi ekonomi di SMAN 1 Sooko mojokerto. (2) Agar mengetahui faktor pendukung yang menjadikan guru ekonomi di SMAN 1 Sooko 
menjadi profesional. (3)Agar memahami faktor yang bisa menjadi penghambat guru ekonomi SMAN 1 Sooko menjadi profesional.

\section{METODE}

Metode penelitian ini menggunakan pendekatan kualitatif-deskriptif, yaitu dengan penelitain partisipan, atau dengan kata lain penulis terjun langsung kedalamnya, meneliti dengan langsung mewawancarai sumber, kemudian mengikuti kegiatan yang dilaksanakan di sana. Dengan Menggunakan teknik wawancara,observasi, serta angket dan kuesioner jika diperlukan secara sistematis dan konsisten bahwa data yang diperoleh, dituangkan dalam suatu rancangan konsep yang kemudian dijadikan dasar utama dalam memberikan analisis. Dalam penelitian ini yang digunakan dalam menganalisa data yang sudah diperoleh adalah dengan cara deskriptif (non statistik), yaitu penelitian yang dilakukan dengan menggambarkan data yang diperoleh dengan kata-kata atau kalimat yang dipisahkan untuk kategori untuk memperoleh kesimpulan (Moleong, 2005).

Sebelum melakukan penelitian ini, peneliti melakukan pengamatan terlebih dahulu pada siswa yang di ajar oleh guru tersebut sebagai objek penelitian mulai dari gaya mengajarnya sampai dengan keseharian guru tersebut di sekolah di waktu keluar dari jam pelajaran, kemudian peneliti mulai merencanakan penelitian dengan mengurus surat-surat ijin yang akan di perlukan sebagai izin untuk melakukan penelitian di sekolah dan di lingkungan tempat kediaman guru berada, setelah itu maka peneliti mulai meneliti dengan wawancara terhadap siswa yng di ambil sampel dengan siswa yang mempunyai nilai tinggi di kelas sebagai objek penelitian untuk ditanya mengenai gaya mengajar guru ekonomi tersebut, setelah itu peneliti melakukan dokumentasi pembelajaran di kelas untuk mengetahui sistem pembelajaran yang di pakai guru tersebut di kelas, dan untuk proses selanjutnya peneliti melakukan wawancara dengan wakil kepala sekolah bidang kurikulum tentang kepribadian guru di sekolah, dan juga menanyakan tentang penyusunan perangkat pembelajaran untuk mengajar selama satu tahun di kelas.

Setelah melakukan wawancara di wakil kepala sekolah bidang kurikulum maka peneliti melanjutkan penelitiannya ke lingkungan tempat kediaman guru tersebut, dengan mewawancarai ketua RT setempat dengan menanyakan bagaimana keseharian guru tersebut di lingkungan tempat kediaman dan juga peneliti ingin mengetahui seberapa jauh pelaksanaan kompe-tensi sosial yang ada di instrumen penelitian yang di gunakan.

Teknik analisis data yang digunakan untuk penelitian ini menggunakan Triangulasi metode dilakukan dengan cara memban-dingkan informasi atau data dengan cara yang berbeda dan dalam penelitian ini ditujukan kepada wakil kepala sekolah bidang kurikulum dan juga para peserta didik serta pada warga masyarakat sekitar kediaman guru ekonomi yang akan diteliti. Sebagaimana dikenal, dalam penelitian kualitatif peneliti menggunakan metode wawancara, obervasi, dan survei. Untuk memperoleh kebenaran informasi yang handal dan gambaran yang utuh mengenai informasi tertentu, peneliti bisa menggunakan metode wawancara bebas dan wawancara terstruktur. Atau, peneliti menggunakan wawancara dan obervasi atau pengamatan untuk mengecek kebenarannya. Selain itu, peneliti juga bisa menggunakan informan yang berbeda untuk mengecek kebenaran informasi tersebut. Melalui berbagai perspektif atau pandangan diharapkan diperoleh hasil yang mendekati kebenaran. Karena itu, triangulasi tahap ini dilakukan jika data atau 
informasi yang diperoleh dari subjek atau informan penelitian diragukan kebenarannya.

\section{HASIL DAN PEMBAHASAN}

Pelakasanaan penelitian tingkat profesionalitas guru ekonomi dalam sistem pembelajaran di SMAN 1 Sooko di lakukan di semster gasal tahun pelajaran 2012/2013. Pembelajaran ekonomi di SMAN 1 Sooko Mojokerto tidak lepas dari program perencanaan, pelaksanaan dan evaluasi pembelajaran karena itulah yang termasuk ke dalam 4 kompetensi yang harus dipenuhi guru dalam mencapai tingkat profesional.

Pada tahap persiapan yang sudah ditentukan oleh pemerintah yaitu dalam hal ini Depdiknas (2004: p.9) mengemukakan kompetensi penyusunan rencana pembelajaran meliputi (1) mampu mendeskripsikan tujuan, (2) mampu memilih materi, (3) mampu mengorganisir materi, (4) mampu menentukan metode/strategi pembelajaran, (5) mampu menentukan sumber belajar/ media/ alat peraga pembelajaran,(6) mampu menyusun perangkat penilaian, (7) mampu menentukan teknik penilaian, dan (8) mampu mengalokasikan waktu. Sejalan dengan hal tersebut, Sholeh (2007) mengungkapkan bahwa perencanaan pembelajaran sangat penting karena seorang guru sejenis apapun punya keterbatasan. Keterbatasan tersebut tentunya harus disadari oleh guru, sehingga mampu menjadi motivator bagi para siswanya saat pembelajaran di kelas.

Berdasarkan uraian di atas, merencanakan program belajar mengajar merupakan proyeksi guru mengenai kegiatan yang harus dilakukan siswa selama pembelajaran berlangsung, yang mencakup: merumuskan tujuan, menguraikan deskripsi satuan bahasan, merancang kegiatan belajar mengajar, memilih berbagai media dan sumber belajar, dan merencanakan penilaian penguasaan tujuan.

Hasil penelitian dari kedua guru ekonomi yaitu Pak Syafii dan Bu woro menunjukkan bahwa dalam tahap persiapan perangkat sebenarnya yang menunjukkan tingkat kesiapan yang lebih baik dari perangkat adalah bu Woro dengan kelengkapannya, disini peneliti melihat perbandingan perangkat yang digunakan oleh kedua guru tersebut.

Setelah di lakukan analisis untuk faktor pendukung tingkat profesionalitas guru ekonomi maka Untuk faktor pendukung dari tingkat profesionalitas guru disini yaitu Guru Ekonomi di SMAN 1 Sooko ini, beliau berdua mempunyai faktor pendukung yang membuat beliau bisa menjadi guru profesional.

Faktor itu antara lain: 1) Adanya keahlian yang dimiliki sebagai guru; 2) Adanya dukungan dari masyarakat; 3) Ada nya dukungan dari rekan guru; 4) Adanya intervensi pemerintah; 5) Adanya tuntutan dari kode etik guru yang mengharuskan untuk guru profesional; 6) Adanya pengawasan dari dinas pendidikan

Inilah faktor penghambat guru ekonomi yang di temukan oleh peneliti pada kedua guru ekonomi di SMAN 1 Sooko karena pada dasarnya Menjadi guru profesional tentu ada banyak tantangan yang harus dihadapi semua guru di Indonesia, begitu juga di SMAN I Sooko kedua guru ekonomi tentu ada faktor penghambat yang menjadi rintangan utama dalam meraih kompetensi profesional, faktor penghambat itu antara lain : 1) Kurangnya pemenuhan jam pelajaran yang ditentukan; 2) Adanya tugas tambahan selain guru; 3) Hubungan sosial dengan rekan guru; 4) Hubungan sosial dengan masyarakat; 5) Metode belajar yang masih belum tepat pada peserta didik 


\section{KESIMPULAN}

Berdasarkan hasil pembahasan yang telah di tulis ada beberapa kesimpulan, Pertama yaitu pada penerapan keprofesionalitasan guru dalam tahap persiapan, pelaksanaan, dan evaluasi pembelajaran di kelas masih dirasa kurang karena pada kenyataannya guru ekonomi masih terkendala dalam hal pembelajaran yang tidak sesuai dengan RPP, dan juga kurang menguasai metode belajar yang baik untuk peningkatan daya tangkap siswa. Kedua yaitu mengenai faktor pendukung utama dalam keprfeionalan guru ekonomi di SMAN 1 Sooko mojokerto yaitu bahwa faktor peningkatan gaji/insentif dari pemerintah yang bisa membuat guru tersebut menjadi profesional karena dengan adanya peningkatan gaji maka kebutuhan guru sehari-hari bisa terpenuhi dan bisa mengajar dengan maksimal. Ketiga yaitu faktor penghambat guru ekonomi SMAN 1 Sooko menjadi profesional yaitu adanya hubungan yang kurang harmonis dengan masyarakat dan rekan guru yang lain, ini menyebabkan seorang guru menjadi tidak maksimal dalam mengajar di kelas, karena seorang guru seharusnya menjadi teladan tidak hanya dalam penguasaan materi pembelajaran namun pada relasi antar sesame rekan guru maupun relasi dengan masyarakat yang terjalin dengan baik.

Saran yang diberikan untuk hasil penelitian ini yaitu bahwa guru seharusnya menguasai metode belajar yang baik untuk meningkatkan daya tangkap siswa terhadap materi yang akan disampaikan, dan juga guru ekonomi seharusnya mendalami rancangan pembelajaran yang telah dibuat karena dari rancangan itulah pembelajaran yang baik akan tercipta.

Faktor pendukung sebaiknya guru tidak hanya berpatokan terhadap gaji yang diberikan kepada pemerintah namun dari dalam diri sendiri yaitu faktor keinginandan semangat yang tinggi untuk bisa menjadi guru profesional sehingga apabila semangat mendidik timbul dari dalam diri guru tersebut maka pembelajaran yang disampaikan akan menjadi maksimal. Sedangkan faktor penghambat sebaiknya guru tersebut menjalankan relasi yang baik dengan semua orang, tidak hanya kepada siswa saja namun juga terhadap wali murid, maupun rekan guru yang lain juga, dengan demikian guru tersebut memang bisa menjadi contoh untuk profesional dimanapun guru tersebut berada, tidak hanya di dalam kelas, namun juga di luar kelas .

\section{DAFTAR RUJUKAN}

Arikunto, Suharsimi (2001) Dasar-dasar Evaluasi Pendidikan. Jakarta: Bumi Aksara. Bhargava, A. \& Pathy, M. (2011) Perseption of student teachers about teaching competencies. Journal of Contemporary Research 1 (1), 77

Moloeng, Lexy J (2005) Metodologi Penelitian Kualitatif, Bandung: PT. Remaja Rosdakarya.

Sholeh, M. (2007) Perencanaan pembelajaran mata pelajaran geografi tingkat SMA dalam konteks KTSP. Jurnal Geografi. 4(2), 1-10

Saragih AH. 2008. Kompetensi minimal seorang guru dalam mengajar. Jurnal Tabularasa PPS UNIMED 5 (1):23-34.

Usman, Moh. Uzer, (1995) Menjadi Guru Profesional. Bandung: PT Remaja Rosdakarya.

Undang-Undang Republik Indonesia Nomor 14 Tahun 2005 tentang Guru dan Dosen

Peraturan Pemerintah (PP) Nomor 19 Tahun (2005) tentang Badan Standar Nasional Pendidikan (BSNP) 